\title{
ISOLATION AND PRIMARY STRUCTURE OF TWO SULFAKININ-LIKE PEPTIDES FROM THE FLESHFLY, NEOBELLIERIA BULLATA
}

\author{
Adrien Fónagy,* Liliane Schoofs, $\ddagger$ Paul Proost, $\S$ Jo Van Damme \\ and ARNOLD DE LOOF
}

*Plant Protection Institute of the Hungarian Academy of Sciences, Budapest II. P.O.B. 102, H-1525, Hungary, Fax: 36-11-769-729; ¥Zoological Institute, Katholieke Universiteit Leuven, Naamsestraat 59, B-3000 Leuven, Belgium; and §Rega Institute, Katholieke Universiteit Leuven, Minderbroedersstraat 10, B-3000 Leuven, Belgium

(Received 21 January 1992; accepted for publication 6 March 1992)

\begin{abstract}
Two novel insect myotropic peptides termed neosulfakinin-I (Neb-SK-I) and neosulfakininII (Neb-SK-II) were isolated from the heads of 42 thousand fleshflies, Neobellieria bullata (Diptera, Sarcophagidae).

2. A series of four, high-performance liquid chromatographic (HPLC), fractionations performed on columns with different characteristic features yielded two purified biologically active, hindgut motility stimulating fractions, suitable for amino acid sequence analysis.

3. The proposed sequences for the two peptides are: Phe-Asp-Asp-Tyr-Gly-His-Met-Arg-Phe-( $\left.\mathrm{NH}_{2}\right)$, (Neb-SK-I) and X-X-Glu-Glu-Gin-Phe-Asp-Asp-Tyr-Gly-His-Met-Arg-Phe-( $\mathrm{NH}_{2}$ ), (Neb-SK-II).

4. These sulfakinins exhibit very high homology to putative drosulfakinin sequences which, however, have not yet been isolated, but were deduced from a cloned Drosophila gene encoding these peptides.

5. Here we provide the first evidence for the expression of such peptides present in Dipterans.

6. Insect sulfakinins show structural identities with the hormonally-active portion of vertebrate gastrin II-, cholecystokinin- and caerulin-related peptides and they share common carboxy terminal sequences with invertebrate/vertebrate peptides of the FMRFamide peptide family.
\end{abstract}

\section{INTRODUCTION}

Fifteen years have elapsed since the first discovery and laborious isolation of the insect neuropeptide proctolin (Starratt and Brown, 1975) has been reported. Since then not only the number of identified insect neuropeptides has grown significantlyprimarily due to the improvement of chromatographical, immunological and molecular biological/ recombinant DNA techniques-but also our knowledge about their role, function and contribution to insect endocrinology has increased.

Besides the rapidly growing structurally characterized insect neuropeptides their nomenclature and classification has evolved tremendously (Raina and Gäde, 1988). Comparative evaluations of these peptides threw a light onto a possibly much closer evolutionary and physiological relation between invertebrates and vertebrates (De Loof, 1987; De Loof and Schoofs, 1990) then previously assumed. A number of peptide hormone groups have been established (for reviews see Holman et al., 1990; De Loof and Schoofs, 1990), the identified members, in most cases, showing significant homology with respective vertebrate (and/or invertebrate) neuropeptides.

Following the pioneering discovery of proctolin (Pea-M), several other peptides have been recently isolated such as the leucokinins (Lem-K-I-VIII), leucopyrokinin (Lem-PK) (Holman et al., 1990). Newly purified and sequenced locustamyotropins (LomMT-I, -IV) and locustapyrokinin (Lom-PK) from
Locusta migratoria (Schoofs et al., 1990a,b, 1991a,b) have carboxy-terminals common with Lem-PK. The locustatachykinins (Lom-TK-I, -IV) from Locusta migratoria bear homologies to peptides of the vertebrate tachykinin family (Schoofs et al., 1990c,d) and yet others, like the Periplaneta americana cardioaccelerating peptides (Pea-CA-I, -II) (Scarborough et al., 1984; Witten et al., 1984) show structural and functional similarities to the insect adipokinetic (AKH) (Stone et al., 1976) or crustacean red pigment concentrating (RPCH) (Fernlund and Josefsson, 1972) hormone group members.

The subgroup of insect sulfakinins (myotropic peptides) contain a sulfated tyrosine residue and may be $N$-terminally blocked with pyroglutamic acid. The leucosulfakinins (Lem-SK-I, -II) (Nachman et al., 1986a,b) were the first isolated members of this group. In P. americana one sulfated form, the perisulfakinin (Pea-SK-I) and a non-sulfated form (otherwise identical to Lem-SK-II) has been isolated too (Veenstra, 1989). More recently another sulfakinin from $L$. migratoria has been purified and identified (Schoofs et al., 1990e). The insect sulfakinins exhibit structural similarities with molluscan cardioaccelerator FMRFamide (Price and Greenberg, 1977), with vertebrate gastrin- and cholecystokinin-related peptides and with the $C$-terminal end of leucomyosuppressin (Lem-MS), a gut motility inhibitory factor (Holman et al., 1986a). Further evidences for the presence of sulfakinin peptides was elucidated by means of molecular biological techniques. Drosophila 
genomic DNA and head cDNA libraries were screened (Nichols et al., 1988) employing oligonucleotide probes designed after Lem-SKs and vertebrate gastrin related peptides. The drosulfakinins (DrmSK-0, Drm-SK-1, Drm-SK-2) have not yet been isolated, but were deduced from the cloned gene encoding cholecystokinin-like precursor. Therefore, it is unknown whether they have similar biological effects to homologous $L$. maderae or L. migratoria peptides or not.

We report here the isolatation, characterization and biological activity of two new insect sulfakinins, termed neosulfakinin-I and neosulfakinin-II or NebSK-I and Neb-SK-II, from head extracts of the fleshfly, Neobellieria bullata (Diptera; Sarcophagidae). Our purification method and the monitoring of biological activity was based upon single response heterologous bioassays (Leucophaea hindgut and $\mathbf{L o}$ custa oviduct) the usefulness of which, in turn may also add to our assumptions concerning endocrinological similarities beween insects.

\section{MATERIALS AND METHODS}

\section{Insects}

Neobellieria bullata (Diptera, Sarcophagidae) was reared under laboratory conditions in mass culture as described by Huybrechts and De Loof (1981). Locusta migratoria $R$ and F were reared according to Ashby (1972). The colonization of Leucophaea maderae was done as reported by Cook and Holman (1978).

\section{Tissue extraction}

The heads of 42,000 7-10 days old male and female flies were cut off during a period of two months. The heads were collected, homogenized and extracted in a methanol/water/acetic acid $(90: 9: 1)$ solution. The homogenates, (each tube contained about 150 heads in $30 \mathrm{ml}$ of extraction mixture) were sonicated, then centrifuged $\left(30 \mathrm{~min}, 10,000 \mathrm{~g}, 4^{\circ} \mathrm{C}\right.$ ) and supernatants of eight tubes were decanted into round bottom flasks. To the pellets $30 \mathrm{ml}$ of extraction solvent was added again. Following resuspension and centrifugation the supernatants were combined and the volatile solvent was removed by rotary evaporation on $30^{\circ} \mathrm{C}$ until only a portion of acetic acid and water remained. This viscous solution was divided into 8 centrifuge tubes to which $15 \mathrm{ml}$ of ethylacetate was added and mixed. After centrifugation $\left(20 \mathrm{~min}, 10,000 \mathrm{~g}, 4^{\circ} \mathrm{C}\right)$ and removal of upper layer, $15 \mathrm{ml} n$ hexane was added, vigorously mixed, then centrifuged again. The lower aqueous portions were pooled into a round bottom flask, then concentrated by rotary evaporation. When about $1-2 \mathrm{ml}$ of extract remained it was resuspended in $0.1 \%$ trifluoroacetic acid (TFA) and subsequently prepurified on Sep-pak cartridges according to Holman et al. (1986b). Aliquots of 100 head equivalents were applied to the cartridges and eluted each time with $30 \%$ acetonitrile in $0.1 \%$ trifluoroacetic acid (TFA) in water. The cartridges were rinsed with $80 \%$ acetonitrile in $0.1 \%$ TFA in water. The $30 \%$ acetonitrile fractions were pooled and evaporated till dryness and kept frozen.

\section{HPLC separation and purification}

HPLC analysis was performed on an LKB Liquid Chromatograph equipped with one pump (LKB 2150), controller (LKB 2152), variable wavelength monitor (LKB 2151) and a mixer driver (LKB 1130). Purification of crude extracts was carried out using subsequently four types of columns with different characteristics. Prior to each purification step, the biologically active fraction was concentrated on a Seppak cartridge.
I. Initial fractionation of prepurified extract was performed on Waters $\mu$-Bondapak phenyl $(30 \mathrm{~cm} \times 4.6 \mathrm{~mm})$ column. Solvent A: $0.1 \%$ TFA in water; Solvent B: $50 \%$ acetonitrile in $0.1 \%$ aqueous TFA. Operating conditions: $100 \%$ A for $8 \mathrm{~min}$, then linear gradient to $100 \%$ B for $120 \mathrm{~min}$; flow rate $1.5 \mathrm{ml} / \mathrm{min}$; detector at 2.56 absorbance range at $214 \mathrm{~nm}$. Fractions were collected arbitrarily every 2 min with an automatic fraction collector (Bio Rad 2110).

II. Secondary fractionation of the biologically active, pooled samples was carried out on Supelcosil $L C-1$ $(25 \mathrm{~cm} \times 4.6 \mathrm{~mm})$ column. Solvent $A$ and $B$, same as during primary fractionation. Operating conditions: $100 \% \mathrm{~A}$ for $6 \mathrm{~min}$, then linear gradient to $100 \%$ B for $80 \mathrm{~min}$; flow rate $1.5 \mathrm{ml} / \mathrm{min}$; detector at 2.56 absorbance range at $214 \mathrm{~nm}$. Fractions were collected automatically every $2 \mathrm{~min}$.

III. Tertiary separation of pooled samples was done on Supelcosil LC $-8(15 \mathrm{~cm} \times 4.6 \mathrm{~mm})$ column. Solvent A and B, same as at primary fractionation. Operating conditions: $100 \% \mathrm{~A}$ for $8 \mathrm{~min}$ then linear gradient to $100 \% \mathrm{~B}$ for $120 \mathrm{~min}$; flow rate $1.5 \mathrm{ml} / \mathrm{min}$; detector at 1.28 absorbance range at $214 \mathrm{~nm}$. Individual peaks were collected manually.

IV. Final purification of biologically active fractions was carried out on Waters Protein Pak $125(30 \mathrm{~cm} \times 7.8 \mathrm{~mm})$ column. Solvent A: $95 \%$ acetonitrile made to $0.01 \%$ TFA; Solvent G: $50 \%$ acetonitrile in $0.01 \%$ aqueous TFA. Operating conditions: $100 \% \mathrm{~A}$ for $8 \mathrm{~min}$ then linear gradient to $100 \%$ B for $80 \mathrm{~min}$; flow rate $1.5 \mathrm{ml} / \mathrm{min}$; detector at 0.32 or 0.16 absorbance ranges at $214 \mathrm{~nm}$. Peaks were collected manually.

To ensure purity, however, the biologically active fractions were rerun on the Protein Pak column under similar conditions as described above.

\section{Bioassays}

For the monitoring of biological (myotropic) activity heterologous bioassays were performed. The preparation of the Leucophaea hindgut bioassay has been described previously (Cook and Holman, 1978). Dissection of Locusta ovaries, preparation of the oviduct (either right or left ovaries were chosen) and bioassays were carried out in Locusta saline as reported previously (Paemen et al., 1990).

\section{Enzymatic analysis}

Prior to amino acid sequencing, dried aliquots, containing approximately 1000 head equivalents of purified peptide was subjected to an aminopeptidase test. The peptide residue was taken up in $150 \mu \mathrm{l}$ insect Ringer solution. To $50 \mu \mathrm{l}$ of immobilized amidopeptidase $M$ (Pierce Chemical Company) containing 0.5 unit $/ \mathrm{ml}, 200 \mu \mathrm{l}$ insect Ringer was added which was centrifuged, resuspended and decanted twice. The dissolved peptide was added to the gel suspension. Following incubation for $2 \mathrm{hr}$ at $37^{\circ} \mathrm{C}$ the gel was removed from the suspension by centrifugation and the supernatant was assayed. When biological activity disappears the $N$-terminal end of the peptide is not blocked. As a control 50 pmole of synthetic locustatachykinin-I (LomTK-I) (Schoofs et al., 1990c) a potent stimulating locust neuropeptide, which is not blocked, was subjected to the enzymatic analysis along with incubation of active sample aliquot in insect saline without the enzyme.

\section{Sequence analysis}

Aliquots of the purified peptide (approximately one third of Neb-SK-I, while total amount of Neb-SK-II, respectively) was degraded sequentially using Edman degradation and the amino acids were converted to the phenylthiodantoin (PTH) derivatives with the Applied Biosystems modes 477A pulsed liquid phase protein sequencer. PTH amino acids were identified with the on-line mode $120 \mathrm{~A} \mathrm{PTH}$ analyser according to the instructions supplied by the 




Fig. 1. HPLC fractionation on Waters- $\mu$-Bondapack-phenyl column of an extract, containing 500 Neobellieria bullata head equivalents. Fractions containing inhibitory $(-)$ or stimulating $(+)$ activity on Leucophaea hindgut and/or Locusta ovary bioassay are shown. Stimulating fractions on Leucophaea hindgut eluting at $54-58 \mathrm{~min}$ are indicated.

manufacturer. The natural peptide was quantified according to the concentrations measured during sequencing.

\section{RFSUITS}

The isolation of the novel neuropeptides from Neobellieria bullata was based upon heterologous bioassay screening method. The present results further proved that this monitoring is an excellent tool for such isolation procedures (Schoofs et al., 1990a,d; $1991 \mathrm{a}, \mathrm{c})$.

A total of 84 -sufficiently reproducible-HPLC runs, each containing approximately 500 head equivalents, were required to process the Speed-Vac concentrated, dried and frozen Sep-pak extracts through the $\mu$-Bondapak phenyl column. In the subsequent process, the relatively small amounts of remaining material allowed us to conduct further purification steps with one or two passes through the $L C-1$ column.

The initial fractionation yielded altogether 16 activating and 1 inhibiting biologically active fraction (Fónagy et al., 1990, 1992) where the activity was observed either on the Leucophaea hindgut or on the
Locusta oviduct or in both assay systems (Fig. 1). The respective, biologically active samples of the $84 \mu$ Bondapak phenyl runs were pooled, concentrated and retained. In this paper we described the subsequent purification of two active fractions eluting at 54-56 min and 56-58 min, on the $\mu$-Bondapak phenyl column (Fig. 1) which stimulate the Leucophaea hindgut, not the oviduct of Locusta.

The biologically active fractions on the $L C-1$ column of area eluting at 54-58 min from $\mu$-Bondapak phenyl column, possessing biological activity, eluted at 14-16 and 16-18 min (Fig. 2). The appropriately pooled samples (i.e. 14-16 $\mathrm{min}$ and $16-18 \mathrm{~min}$ samples, respectively) were subjected to the next purification step to the $L C-8$ column separation, where both samples partially showed the presence of similar materials indicating a possible overlap at respective areas (Figs $3 a$ and $4 a$ ). The further purification of $L C-1 \quad 14-16 \mathrm{~min}$ samples yielded an active fraction at $55 \mathrm{~min}$ on $L C-8$ column, while the 16-18 min samples revealed two fractions on $L C-8$ column one fraction at $55 \mathrm{~min}$ and another at $57 \mathrm{~min}$. When the pooled peaks eluting at $55 \mathrm{~min}$ on the $C-8$ column (Figs $3 a$ and $4 a$ ) were finally purified on



Fig. 2. Fractionation on Supelcosil LC -1 column of area indicated on Fig. 1. Myotropic activity eluted in 2 fractions as indicated, at $14-16$ and $16-18 \mathrm{~min}$, respectively. 




Fig. 3a. Fractionation on Supelcosil LC-8 column of area eluting at 14-16 min on Supelcosil LC-1 column. An active fraction at $55 \mathrm{~min}$ is indicated.

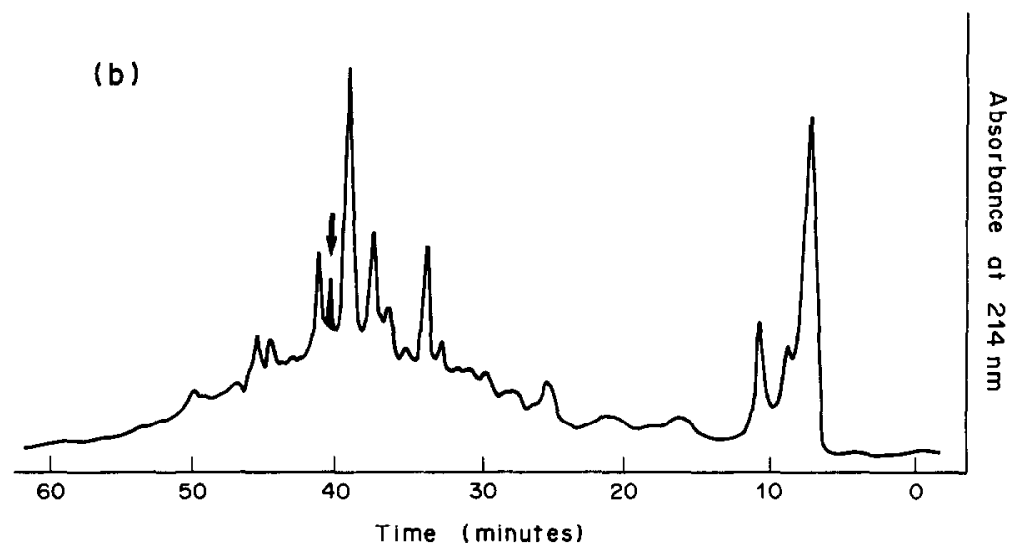

Fig. 3b. Fractionation on Waters Protein Pak column of pooled fractions indicated on Fig. 3a and Fig. 4a (both eluting at $55 \mathrm{~min}$ ). Neosulfakinin-I eluted at $40.5 \mathrm{~min}$.

Protein Pak column the presence of three different peptides was revealed each eluting at $39,40.5$ and $41 \mathrm{~min}$, respectively, each peak showing strong stimulating activity on Leucophaea hindgut bioassay (Fig. 3b). An aliquot of the peak eluting al $40.5 \mathrm{~min}$ was subjected to enzymatic analysis, then amino acid sequencing. Further purification of the $57 \mathrm{~min}$ fraction of the $L C-8$ column on the Protein Pak column resulted in an active peak eluting at $48 \mathrm{~min}$ (Fig. 4b).

The enzymatic analysis tests indicated that the $N$-terminals of the newly isolated two peptides are most likely not blocked, consequently they could be directly subjected to amino acid sequencing. An aliquot (one third, $30 \mathrm{pmol}$ ) of the $40.5 \mathrm{~min}$ peak was used for amino acid sequencing. The primary structure of this peptide was determined to be:

\section{Phe-Asp-Asp-Tyr-Gly-His-Met-Arg-Phe}

(MW: 1047)

A total amount of about $100 \mathrm{ng}(90 \mathrm{pmol})$ of Neb-SK-I was isolated. The activity of the natural extract is proposed to be in the $1.5 \times 10^{-10} \mathrm{M}$ range as found on the Leucophaea hindgut bioassay. The total amount of the second peptide $(15 \mathrm{pmol})$ was subjected to sequencing and the primary amino acid sequence of the second sulfakinin is as follows:

\section{X-X-Glu-Glu-Gln-Phe-Asp-Asp}

$$
\text { -Tyr-Gly-His-Met-Arg-Phe }
$$

(Putative MW: 1700)

The first two $N$-terminal amino acids could not be identified due to the small amount of isolated peptide available. This newly isolated peptide may be termed as Neb-SK-II. An amount of $26 \mathrm{ng}$ has been isolated. The activity of the natural peptide is estimated to be in the $5 \times 10^{-11} \mathrm{M}$ range.

The sulfated synthetic replicas in the amidated and acid form will elucidate whether the purified peptide is sulfated and $C$-terminally amidated. Further biological studies will be carried out with the availability of synthetic peptides.

\section{DISCUSSION}

In this paper we described the isolation and biological activity of two structurally very similar insect sulfakinins, Neb-SK-I and Neb-SK-II. These two peptides bear substantial importance from several aspects as will be discussed below. 




Fig. 4a. Fractionation on Supelcosil LC-8 column of area eluting at 16-18 min on Supelcosil LC-1 column. Active fractions at 55 and $57 \mathrm{~min}$ are indicated, respectively.

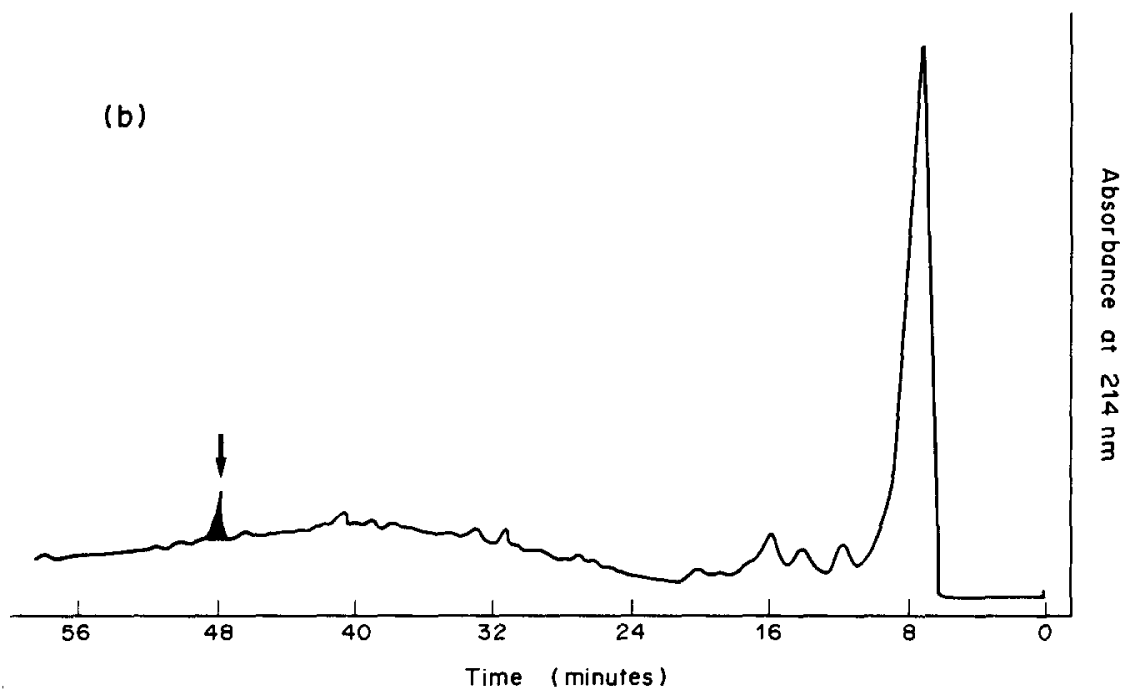

Fig. 4b. Fractionation on Waters Protein Pak column of fraction eluting at $57 \mathrm{~min}$ on Supelcosil LC'-8 column. Neosulfakinin-II eluted at $48 \mathrm{~min}$.

The Neb-SK-I and II are the first myotropic peptides isolated from the fleshfly, Neobellieria bullata and from Diptera. We assume, that the newly isolated peptides are $C$-terminally amidated and are sulfated at Tyr, as was generally pointed out for other isolated insect sulfakinins (Nachman et al., 1986a,b; Veenstra, 1989). The sulfate group could have been, however, removed during sequencing or might be absent as shown for a non-sulfated peptide isolated from $P$. americana (but otherwise identical to Lem-SK-II) (Veenstra, 1989). Interestingly, the neosulfakinins are not blocked by pyroglutamic acid at $N$-terminals, a structural feature quite common in insect hormones or some vertebrate hormones.

In addition to the laborious works performed with Leucophaea maderae (for review see Holman et al., 1990) and Locusta migratoria (Schoofs et al., $1990 \mathrm{a}, \mathrm{b}, \mathrm{c}, \mathrm{d} ; 1991 \mathrm{a}, \mathrm{b}, \mathrm{c})$ regarding the discovery of different myotropins, the presented results show that myotropins are widespread in insect brains and have essential regulatory functions. Some of the insect myotropic peptide families described so far show strong structural resemblence and/or homologies to other vertebrate/invertebrate brain-gut peptides (De Loof and Schoofs, 1990). The Locusta tachykinins correspond to the vertebrate tachykinin family-of which mammalian substance $P$ is the best known member (Chang, 1971)-and their presence in both vertebrates and invertebrates suggest that they play an important and conserved physiological role i.e. smooth muscle motility induction (Schoofs et al., $1990 \mathrm{c}, \mathrm{d})$. Insect sulfakinins exhibit partial sequence homology with the active $C$-terminal sequences, of the human brain-gut peptides the gastrin II (responsible for gastric secretion, smooth muscle contraction etc.) and cholecystokinin (CCK) (known to stimulate pancreatic enzyme secretion or involved in the mechanism of satiery etc.) or with caerulin (exhibits activity similar to CCK) (Table 1).

Nichols et al. (1988) have cloned CCK-like precursors from Drosophila encoding three putative peptides, Drm-SK-0, Drm-SK-I and Drm-SK-II, 
Table 1. Sequence homologies between vertebrate gastro-intestinal-related peptides and identified insect sulfakinins

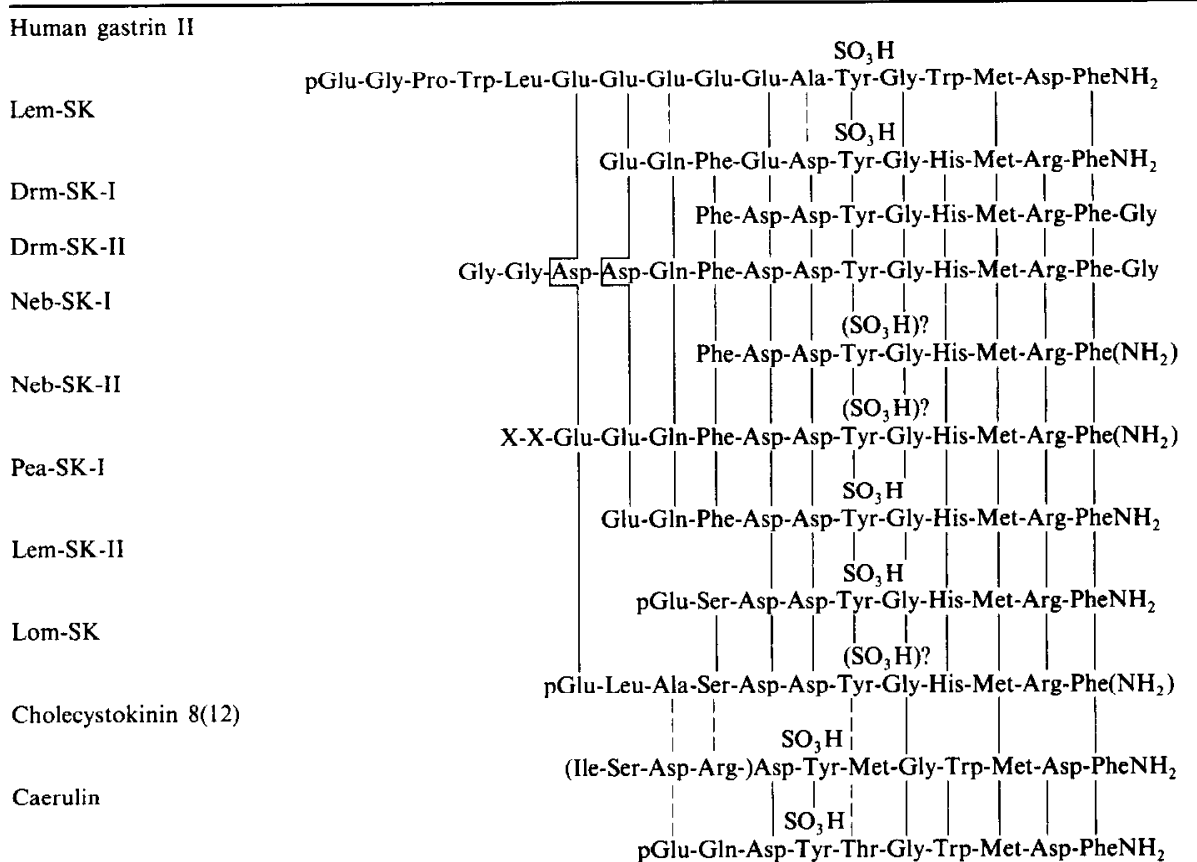

Solid lines indicate identical amino acids and dashed lines correspond to residues in which the nucleotide codons may differ by a single nucleotide.

spectively. Synthetic replicas of the two latter ones exhibited myotropic activity on the isolated cockroach hindgut bioassay (Holman, unpublished observations), but so far the native peptides have not yet been isolated. The present report on the identification of Neb-SK-I and Neb-SK-II from another Dipteran species provides biological proof of that the sulfakinins are expressed in Dipterans as it was proposed. These results also contribute to the immunocytochemical works of Duve and Thorpe (1981, 1984) who provided substantial evidence that gastrin-CCK immunoreactive material is present in nervous system of Calliphora species, and that the peptidergic innervation could be related to digestive functions and muscular movement of the gut.

Neb-SK-I, Neb-SK-II, Drm-SK-I and Drm-SK-II all have the $C$-terminal nonapeptide Phe-Asp-AspTyr-Gly-His-Met-Arg-Phe (amide) in common. Moreover, the primary structure of Neb-SK-I and Drm-SK-I are identical, but since the Drm-SK-I putative sequence is based on molecular cloning techniques, we propose for this newly isolated peptide to be termed as Neb-SK-I. Neb-SK-II differs from Drm-SK-II only in its $N$-terminal tetrapeptide sequence from which at least two amino acids are different.

It is interesting to mention that Neb-SK-II contains Lem-SK as its $C$-terminal undecapeptide except for Asp at position 8 from the $C$-terminal which is Glu in Lem-SK. Hence, Neb-SK-II is more related to Lem-SK than Drm-SK-II. The most striking similarity is found, however, between Neb-SK-II and Pea-SK-I as for the $C$-terminal sequence. The difference lies in the $N$-terminal portion of the Neb-SK-II since it is a tetradecapeptide vs Pea-SK-I which is an undecapeptide (Table 1).
Insect sulfakinins are evolutionarily related to vertebrate CCK and gastrin (Nachman et al., 1986a,b). However, unlike Lem-SK-II and Lom-SK which are more related to CCK 12 (Nachman et al., 1986a,b; Schoofs et al., 1990d) Neb-SK-II is likely to exhibit more structural similarities with gastrin II. Neb-SK-II has six amino acids at identical positions in common with gastrin II $\mathrm{Glu}^{3}, \mathrm{Glu}^{4}$, $\mathrm{Tyr}^{9}, \mathrm{Gly}^{10}, \mathrm{Met}^{12}, \mathrm{Phe}^{14}$ ) and only five (of which three are at identical positions) with CCK 12. Moreover, sequence similarity with gastrin II may be even greater, since an additional three amino acids could result from single base substitutions ( $\mathrm{Gln}^{5}$ vs $\mathrm{Glu}^{8} ; \mathrm{Asp}^{7}$ vs $\mathrm{Glu}^{10} ; \mathrm{Asp}^{8}$ vs $\mathrm{Ala}^{11}$ ) of respective codons.

The discovery of these new sulfakinins underline the hypothesis that almost identical peptides may be present in closely related species and that peptides may have common evolutionary origin and conserve successful structures and moreover exert similar action (De Loof and Schoofs, 1990). A further proof is presented that the identity between $\mathrm{CCK}$-gastrincaerulin related peptides and insect sulfakinins is greater towards the $C$-terminal end than towards the $N$-terminal, which is a common tendency in this peptide family (Larsson and Rehfeld, 1977). The bioactive $C$-terminals (heptapeptide portion) of insect sulfakinins seem to be highly conserved structures (Nachman 1986a), while the $N$-terminals are more variable. The insect sulfakinins are all common in the $\mathrm{Asp}^{7(8)}, \mathrm{His}^{4(5)}$ and $\mathrm{Arg}^{2(3)}$ (matched from $\mathrm{C}$ terminal) positions but on the other hand distinguish them from vertebrate gastrin-related peptides (Table 1). It should be noted that these peptides also share another common feature with Lem-SK-I, II, Pea-SK-I and Lom-SK, namely that the last three 
amino acids are identical to those of FMRF-amide related peptides (Price and Greenberg, 1977).

The conserved gastrointestinal myotropic function of these newly isolated sulfakinins is further strengthened, based on the fact that they were active on the Leucophaea hindgut assay but were inactive on Locusta oviduct bioassay. Both biological and chemical similarities between vertebrate and invertebrate gastrointestinal peptides substantiate the evidence for a long evolutionary history of this peptide family.

Acknowledgement - The Hungarian "Soros Foundation" and the Catholic University of Leuven for providing a research grant for Dr A. Fónagy is specially acknowledged. We thank Dr S. Matsumoto for critical reading of manuscript and Ms Kristine Pycke for technical assistance. This project was supported by the I.W.O.N.L. and N.F.W.O. of Belgium.

\section{REFERENCES}

Ashby G. J. (1972) Locusts. In The UFAW handbook on the care and management of laboratory animals (Edited by UFAW), pp. 582-587. Churchill Livingstone, Edinburgh.

Chang M. M., Leeman S. E. and Niall H. D. (1971) Aminoacid sequence of substance $P$. Nature 232, 86-87. Cook B. J. and Holman G. M. (1978) Comparative pharmacological properties of muscle functions in the foregut and the hindgut of the cockroach Leucophaea, maderae, Comp. Biochem. Physiol. 61C, 291-295.

De Loof A. (1987) The impact of the discovery of vertebrate-type steroids and peptide hormone-like substances in insects. Entomol. Exp. Appl. 45, 105-113.

De Loof A. and Schoofs L. (1990) Homologies between the amino acid sequences of some vertebrate peptide hormones and peptides isolated from invertebrate sources. Comp. Biochem. Physiol. 95B, 459-468.

Duve H. and Thorpe A. (1981) Gastrin/cholecystokinin (CCK)-like immunoreactive neurons in the brain of the blowtly, Calliphora erythrocephala (Diptera). Gen. comp. Endocrinol. 43, 381-391.

Duve H. and Thorpe A. (1984) Immunocytochemical mapping of gastrin/CCK-like peptides in the neuroendocrine system of the blowfly, Calliphora vomitoria (Diptera). Cell Tissue Res. 237, 309-320.

Fernlund P. and Josefsson L. (1972) Crustacean color change hormone: amino acid sequence and chemical synthesis. Science 177, 173-175.

Fónagy A., Schoofs L., Van Damme J., Billiau A. and De Loof A. (1990) The isolation and purification of novel myotropic peptides from the fleshfly, Neobellieria bullata (Diptera, Sarcophagidae). In Abs. Vol. 15th Conf. of European Comparative Endocrinologists. Leuven, Belgium. pp. 42.

Fónagy A., Schoofs L., Proost P., Van Damme J., Bueds H. and De Loof A. (1992) Isolation, primary structure and synthesis of neomyosuppressin, a myoinhibiting neuropeptide from the grey fleshfly, Neobellieria bullata. Comp. Biochem. Physiol. 102, 239-245.

Holman G. M., Cook B. J. and Nachman R. J. (1986a) Isolation, primary structure and synthesis of leucomyosuppressin, an insect neuropeptide that inhibits the spontaneous contractions of the cockroach hindgut. Comp. Biochem. Physiol. 85C, 329-333.

Holman G. M., Cook B. J. and Nachman R. J. (1986b) Isolation, primary structure and synthesis of two neuropeptides from Leucophaea maderae: members of a new family of cephalomyotropins. Comp. Biochem. Physiol. 84C, 205-211.
Holman G. M., Nachman R. J. and Wright M. S. (1990) Insect neuropeptides. Annu. Rev. Entomol. 35, 201-217.

Huybrechts R. and De Loof A. (1981) Effect of ecdysterone on vitellogenin concentration in haemolymph of male and female Sarcophaga. Int. J. Invert. Reprod. 3, 157-168.

Larsson L. I. and Rehfield J. F. (1977) Evidence for a common evolutionary origin of gastrin and cholecystokinin. Nature 269, 235-238.

Nachman R. J., Holman G. M., Cook B. J., Haddon W. F. and Ling N. (1986a) Leucosulfakinin-II, a blocked sulfated insect neuropeptide with homology to cholecystokinin and gastrin. Biochem. Biophys. Res. Commun. 140, 357-364.

Nachman R. J., Holman G. M., Haddon W. F. and Ling N. (1986b) Leucosulfakinin, a sulfated insect neuropeptide with homology to gastrin and cholecystokinin. Science 234, 71-73.

Nichols R., Schneuwly S. A. and Dixon J. E. (1988) Identification and characterization of a Drosophila homologue to the vertebrate neuropeptide cholecystokinin. $J$. biol. Chem. 263, 12167-12170.

Price D. and Greenberg M. (1977) Structure of molluscan cardioexcitatory neuropeptide. Science 189, 670-671.

Raina A. K. and Gäde G. (1988) Insect peptide nomenclature. Insect Biochem. 18, 785-787.

Scarborough, R. M., Jamieson G. C., Kalish F., Kramer S. J. and McEnroe G. A. (1984) Isolation and primary structure of two peptides with cardioacceleratory and hyperglycemic activity from corpora cardiaca of Periplaneta americana. Proc. Natl. Acad. Sci. U.S.A. 81, 5575-5579.

Schoofs L., Holman G. M., Hayes T. K., Tips A., Nachman R. J., Vandesande F, and De Loof A. (1990a) Isolation, identification and synthesis of locustamyotropin (LomMT), a novel biologically active insect neuropeptide. Peptides 11, 427-433.

Schoofs L., Holman G. M., Hayes T. K., Nachman R. J. and De Loof A. (1990b) Isolation, identification and synthesis of locustamyotropin II, an additional neuropeptide of Locusta migratoria: member of the cephalomyotropic peptide family. Insect Biochem. 20, 479-484.

Schoofs L., Holman G. M., Hayes T. K., Nachman R. J. and De Loof A. (1990c) Locustatachykinin I and II, two novel insect neuropeptides with homology to peptides of the vertebrate tachykinin family. FEBS Lett. 261, $397-401$.

Schoofs L., Holman G. M., Hayes T. K., Kochansky J., Nachman R. J. and De Loof A. (1990d) Locustatachykinin III and IV: two additional insect neuropeptides with homology to peptides of the vertebrate tachykinin family. Regul. Peptides 31, 199-212.

Schoofs L., Holman G. L., Hayes T. K., Nachman R. J. and $\mathrm{De}$ Loof $\mathrm{A}$. (1990e) Isolation and identification of sulfakinin-like peptide with sequence homology to vertebrate gastrin and cholecystokinin from the brain of Locustya migratoria. In Chromatography and Isolation of Insect Hormones and Pheromones (Edited by McCaffery A. and Wilson I.) pp. 231-241. Plenum Press, New York.

Schoofs L., Holman G. M., Hayes T. K., Nachman R. J., Kochansky J. P. and De Loof A. (1991a) Isolation, identification and synthesis of locustamyotropin III and IV, two additional neuropeptides of Locusta migratoria: members of the locustamyotropin peptide family. Insect Biochem. (in press).

Schoofs L., Holman G. M., Hayes T. K., Nachman R. J. and De Loof A. (1991b) Isolation and identification of locustapyrokinin, a myotropic peptide from Locusta migratoria. Gen. comp. Endoc. 81, 97-104.

Schoofs L., Holman G. M., Proost P., Van Damme J., Hayes T. K. and De Loof A. (199/c) Locustakinin, a novel myotropic peptide from the Locusta migratoria, 
isolation, primary structure and synthesis. Regul. Peptides (in press)

Starratt A. N. and Brown B. E. (1975) Structure of pentapeptide proctolin, a proposed neurotransmitter in insects. Life Sci. 17, 1253-1256.

Stone J. V., Mordue W., Batley K. E. and Morris H. R. (1976) Structure of locust adipokinetic hormone, a neurohormone that regulates lipid utilization during flight. Nature 263, 207-211.
Veenstra J. A. (1989) Isolation and structure of two gastrin/CCK-like neuropeptides from the American cockroach homologous to the leucosulfakinins. Neuropeptides 14, 145-149.

Witten J. L., Schaffer, M. H., O'Shea M., Cook J. C., Hemling M. E. and Rinehart K. L. (1984) Structures of two cockroach neuropeptides assigned by fast atom bombardment mass spectrometry. Biochem. Biophys. Res. Commun. 124, 350-358. 